\title{
Tonic GABAergic Inhibition of Sympathetic Preganglionic Neurons: A Novel Substrate for Sympathetic Control
}

\author{
LiHua Wang, Emma Spary, Jim Deuchars, and Susan A. Deuchars \\ Institute of Membrane and Systems Biology, University of Leeds, Leeds LS2 9JT, United Kingdom
}

\begin{abstract}
The sympathetic tone is primarily defined by the level of activity of the sympathetic preganglionic neurons. We report a novel inhibitory influence on sympathetic activity, that of tonic GABAergic inhibition which could have a profound global effect on sympathetic outflow. Recording from identified SPNs in the intermediolateral cell column (IML) of rat spinal cord slices, application of the GABA receptor antagonist bicuculline, but not gabazine, elicited a change in voltage that lasted for the duration of application. This response was mediated by a direct effect on SPNs since it persisted in tetrodotoxin and low $\mathrm{Ca}^{2+} / \mathrm{high} \mathrm{Mg}^{2+}$ and the amplitude of responses were related to $\mathrm{Cl}^{-}$concentration in patch solutions. Such tonic inhibitory responses were not observed in interneurons, the other neuronal type in the IML, although ongoing IPSPs were antagonized in these neurons. The effects of bicuculline were enhanced by diazepam but not zolpidem or the GABA modulators THIP and THDOC suggesting a role for $\alpha 5$ subunits. PCR using primers for the $\alpha 5$ and $\delta$ subunits indicated the presence of $\alpha 5$, but not $\delta$ subunits in the IML. Firing rates of SPNs were enhanced by bicuculline and decreased by diazepam indicating that this tonic inhibition has a profound effect on the excitability of SPNs. These data indicate a novel influence for controlling the activity of SPNs regardless of their function.
\end{abstract}

Key words: sympathetic preganglionic; spinal cord; GABA; electrophysiology; PCR; patch clamp

\section{Introduction}

Alterations in the activity of the sympathetic nervous system are key contributors to changes in cardiovascular variables in many conditions such as heart failure, renal failure and hypertension (Tentolouris et al., 2006; Francischetti and Genelhu, 2007). One avenue for therapeutic intervention is therefore sympathetic inhibition.

Interventional treatment for hypertension acting through the CNS could be better designed with a clearer understanding of the precise neuronal circuitry underlying control of cardiovascular output and the properties of the neurons within these networks. Many CNS regions and neuronal types shape the level of sympathetic activity by ultimately influencing spinal sympathetic preganglionic neurons (SPNs), the sole sympathetic output from the CNS. A large component of this control is due to activation of inhibitory neurons, both local (Deuchars, 2007) and from descending pathways (Dembowsky et al., 1985; Deuchars et al., 1997), that impinge on SPNs. Phasic inhibition, due to release of GABA and glycine at synapses, is important in setting the pattern of firing in the SPNs since an inhibitory synaptic input will take the neuron away from the threshold for firing and reset the level of excitability. A second group of receptors, distinct from postsynaptic receptors, can be continuously activated by low am-

Received June 26, 2008; revised 0ct. 9, 2008; accepted 0ct. 13, 2008.

We thank the British Heart Foundation (Grant PG/2001119 to S.A.D. and J.D.) and Research Councils UK for their generous support. We also thank Brenda Frater for her skilled technical contribution.

Correspondence should be addressed to Susan A. Deuchars, Institute of Membrane and Systems Biology, University of Leeds, Leeds LS2 9JT, UK. E-mail: S.A.Deuchars@leeds.ac.uk.

DOI:10.1523/JNEUROSCI.2951-08.2008

Copyright $\odot 2008$ Society for Neuroscience $\quad 0270-6474 / 08 / 2812445-08 \$ 15.00 / 0$ bient levels of neurotransmitter. These receptors are located away from synapses and so are called perisynaptic or extrasynaptic receptors. A GABA-mediated tonic inhibition was first reported in dentate gyrus granule cells (Otis et al., 1991) and since then, tonic inhibition has been reported in a variety of regions of the CNS, for example cerebellum, hippocampus, dentate gyrus, cortex, thalamus and brainstem (for review, see Semyanov et al., 2004; Glykys and Mody, 2007). The crucial characteristic of this inhibition is that, in contrast to event-based synaptic activity, tonic current continuously influences cell excitability and if present in SPNs, this could have widespread effects on sympathetic outflow. Changes in the levels of tonic inhibition in SPNs could also have profound pathological implications since this would lead to altered sympathetic outflow to many end organs. Indeed in other CNS regions, reductions of tonically active currents have been implicated in certain animal models of epilepsy (Peng et al., 2004; Zhang et al., 2007) while mutations of the GABRG2 gene known to cause specific generalized epilepsies with febrile seizures reduced tonic GABA currents (Eugène et al., 2007). Thus, the discovery of tonic GABAergic currents in other CNS regions has opened new avenues for treatment of specific disease states (Meldrum and Rogawski, 2007).

In this study, we provide the first evidence for a tonic GABAergic inhibition that regulates the firing rate of SPNs in the thoracic intermediolateral cell column (IML) of spinal cord slices. Several pharmaceuticals acting on $\mathrm{GABA}_{\mathrm{A}}$ receptors are known to influence blood pressure (Marty et al., 1986; Taneyama et al., 1993). This study suggests that a component of this effect could be mediated via tonic inhibition and consequently that tonic inhibition may be one target for CNS-mediated therapeutic actions on the cardiovascular system. 


\section{Materials and Methods}

Electrophysiology. Rats of either sex aged 10-15 $\mathrm{d}$ were anesthetized with urethane $(2 \mathrm{~g} / \mathrm{kg}$, i.p.) and perfused with ice-cold sucrose (215 mM) aCSF. The upper and middle thoracic spinal cord was removed and sectioned $(300 \mu \mathrm{m}$ thick). Slices were then superfused at a rate of 3-5 $\mathrm{ml} / \mathrm{min}$ in aCSF (Deuchars et al., 2001) [composition (in mM): $124 \mathrm{NaCl}, 26 \mathrm{NaHCO}_{3}$, $3 \mathrm{KCl}, 2 \mathrm{MgSO}_{4}, 2.5 \mathrm{NaH}_{2} \mathrm{PO}_{4}, 2 \mathrm{CaCl}_{2}, 10$ glucose], equilibrated with $95 \% \mathrm{O}_{2} / 5 \% \mathrm{CO}_{2}$ that also contained $2 \mathrm{~mm}$ kynurenic acid, an excitatory amino acid receptor antagonist. SPNs within the IML were targeted, identified both electrophysiologically and anatomically as previously (Deuchars et al., 2001). Interneurons [identified as described by Deuchars et al., (2001)] in this region were also recorded to determine whether the tonic inhibition was confined to SPNs.

Whole-cell patch-clamp recordings were made in current-clamp mode from SPNs and interneurons using an Axopatch 1D (Axon Instruments). Patch electrodes (tip diameter 3 $\mu \mathrm{m}$, resistance $4-6 \mathrm{M} \Omega$ ) were filled with 3 different patch solutions that gave different chloride reversal potentials $\left(\mathrm{E}_{\mathrm{Cl}}\right)$, calculated at room temperature using the Nernst Equation. Intracellular composition (in $\mathrm{mm}$ ) of K-gluconate based: $110 \mathrm{~K}$-gluconate, 11 EGTA, $2 \mathrm{MgCl}_{2}, 0.1$ $\mathrm{CaCl}_{2}, 10$ HEPES, $2 \mathrm{Na}_{2} \mathrm{ATP}$, and $0.3 \mathrm{Na}_{2} \mathrm{GTP}$; Cs based: $110 \mathrm{Cs}_{2} \mathrm{SO}_{4}, 0.5 \mathrm{CaCl}_{2}, 2 \mathrm{MgCl}_{2}, 5$ EGTA, 5 HEPES, $5 \mathrm{Na}_{2}$ ATP, 5 TEA; KCl based: $140 \mathrm{KCl}, 1 \mathrm{CaCl}_{2}, 1 \mathrm{MgCl}_{2}, 10$ EGTA, 10 HEPES, 3 Mg-ATP, $0.3 \mathrm{Na}_{2}$ GTP, pH 7.2, 295 mOsm.

The lateral funiculus (Lf) was stimulated with single pulses, using bipolar stimulating electrodes and isolated stimulators (Digitimer DS2A) to elicit IPSPs at depolarized potentials $(-20$ to $+10 \mathrm{mV})$. The input resistance of neurons was calculated as the voltage response to a hyperpolarizing current pulse using the equation $R=V / I$ where $R$ is the input resistance, $V$ is the voltage deflection and $I$ is the current pulse amplitude. The downward deflections in the voltage traces (see Figs. $1 A, 4 A, C 1$ ) are in response to these hyperpolarizing current pulses that were applied every 5-10 s.

Drugs were applied in the superfusing solution and the concentration is the final concentration in the bath. Drugs used were GABA, GABA $\mathrm{A}_{\mathrm{A}}$ angonists (bicuculline, picrotoxin and gabazine) and modulators (diazepam, zolpidem, THIP and THDOC), a glycinergic antagonist strychnine, a GABAB antagonist CGP55845A and tetrodotoxin. All drugs were from Sigma, apart from bicuculline and CGP55845A which were from Tocris. Picrotoxin and bicuculline are both used at a high concentration (100 $\mu \mathrm{M}$ as shown) since a saturated concentration is always necessary for receptors with high affinity to neurotransmitter and less desensitization. Strychnine is considered as a selective glycine receptor antagonist; however, it may cross-react on GABA-A receptors when concentrations are $>1 \mu \mathrm{M}$ (Li et al., 2003), so a concentration of $100 \mathrm{~nm}$ was used since this should be completely effective at glycine receptors (Hussy et al., 1997; Ghavanini et al., 2005).

Data analysis. Voltage responses of the recorded neurons were monitored throughout experiments. Recordings were terminated in all experiments if the baseline was unstable or discontinuous. Control condition $\left(\Delta V_{\text {con }}\right)$ was calculated as the membrane potential difference at $2 \mathrm{~min}$ $\left(V_{1}\right)$ and $30 \mathrm{~s}\left(V_{2}\right)$ before drug application $\left(\Delta V_{\text {con }}=V_{2}-V_{1}\right)$. Drug induced membrane potential changes $\left(\Delta V_{\text {drug }}\right)$ were the difference between peak responses $\left(V_{3}\right)$ and $V_{2}\left(\Delta V_{\text {drug }}=V_{3}-V_{2}\right)$. Although no measurement or statistical analysis was applied to washout of a drug effect, pooled data did not include any recordings where no recovery of membrane potential could be observed upon $10 \mathrm{~min}$ of washout. The effects of drug were determined by the differences between $\Delta V_{\text {con }}$ and $\Delta V_{\text {drug }}$ using Student's $t$ test as detailed in results. Significance was considered when $p<0.05$.

The amplitudes of evoked postsynaptic potentials were averaged and changes in amplitude were compared using Student's paired $t$ test and considered significant at $p<0.05$.

$R N A$ extraction and PCR. Total RNA was isolated from micropunches of IML and spinal cord slices of rats (10-15 d), anesthetized and prepared as described above. The RNA was reverse transcribed as previously described (Spary et al., 2008). PCR was performed with $0.4 \mu \mathrm{M}$ primers $(\alpha 5$ forward 5', TGACCAAAACCCTCCTTGTCTTCT- $3^{\prime}, \alpha 5$ reverse $5^{\prime}$, ACCGCAGCCTTTCATCTTTCC- ${ }^{\prime} ; \delta$ forward $5^{\prime}$, GCCAAGTCTGCCTGGTTCCA-3', $\delta$ reverse $5^{\prime}$, GGAGACCCAGGACATGGCAA-3') (Spary et al., 2008).

Reactions using cDNA extracted from the hypothalamus acted as a positive control. Negative controls included $\mathrm{dH}_{2} \mathrm{O}$ and RNA, which had not undergone reverse transcription. PCR products were confirmed by DNA sequencing (ABI 3130XL).

\section{Results}

$\mathrm{A} \mathrm{GABA}_{\mathrm{A}}$ receptor-mediated tonic inhibition is present in SPNs

Using K-gluconate-based intracellular solution, bath application of bicuculline (2-100 $\mu \mathrm{M})$ to SPNs did not induce obvious mem- 


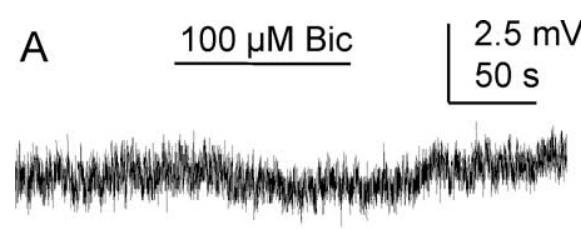

in $1 \mu \mathrm{M} \mathrm{TTX}$
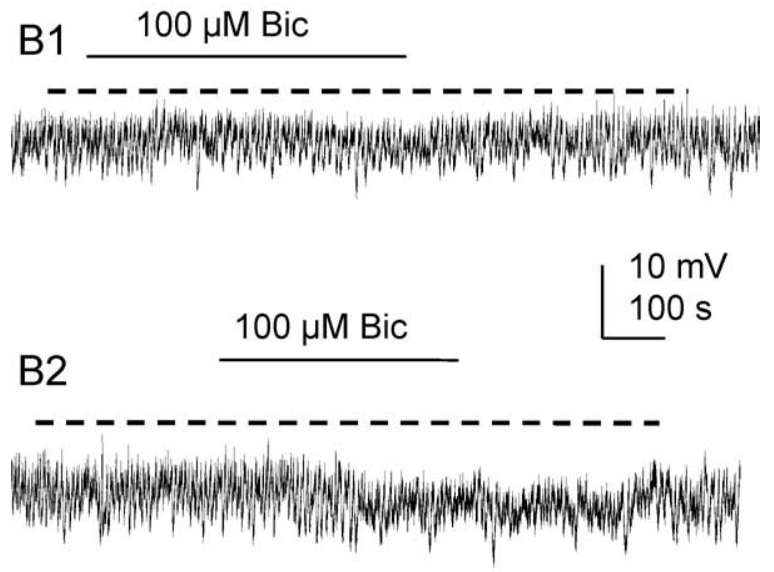

in $2.5 \mu \mathrm{M}$ GABA

Figure 2. Tonic inhibition is also observed in KCl-based intracellular solution and is enhanced by low concentrations of GABA.A, At resting membrane potential and in the presence of extracellular TTX (1 $\mu \mathrm{M})$, this SPN was hyperpolarized by $100 \mu \mathrm{m}$ bicuculline. B1, Recording from another SPN where $100 \mu \mathrm{m}$ bicuculline elicited a small hyperpolarization. $\boldsymbol{B} 2$, In the presence of applied GABA, bicuculline caused a larger shift in membrane potential.

brane potential changes $(0.2 \pm 0.4 \mathrm{mV}$ to $0.8 \pm 0.6 \mathrm{mV}, n=11$, $p>0.05)$ when cells were held at resting membrane potentials (Fig. 1A). When cells were manually depolarized to $0 \mathrm{mV}$ to increase chloride driving potential, $100 \mu \mathrm{M}$ bicuculline caused membrane depolarizations in all SPNs recorded, with an average amplitude of $4.4 \pm 0.5 \mathrm{mV}(n=12, p<0.001)$ (Fig. $1 B)$, associated with an increase in whole-cell input resistance $(\mathrm{M} \Omega)$ of $20.45 \pm 11.3 \%$. Upon repetitive applications of bicuculline, no apparent desensitization was observed. This response was also maintained in the presence of $1 \mu \mathrm{M}$ external TTX $(11.4 \pm 3.4 \mathrm{mV}$, $n=4, p<0.001$ ) (Fig. $1 B$ ). A noncompetitive $\mathrm{GABA}_{\mathrm{A}}$ receptor antagonist picrotoxin $(100 \mu \mathrm{M})$ also induced a membrane depolarization in all 4 neurons recorded with mean amplitude of $4.0 \pm$ $1.4 \mathrm{mV}(p<0.05)$. This response was also observed when $1 \mu \mathrm{M}$ TTX was added into perfusion solution (Fig. 1C).

Metabotropic $\mathrm{GABA}_{\mathrm{B}}$ receptors are also expressed in SPNs (Whyment et al., 2004); therefore, the effect of the $\mathrm{GABA}_{\mathrm{B}}$ antagonist CGP55845A was examined. Application of $200 \mathrm{~nm}$ CGP55845A did not elicit a membrane potential shift in any SPN (Fig. 1D), although this concentration completely antagonized responses induced by baclofen (data not shown). The glycine receptor antagonist, strychnine (100 nM), was also without effect on membrane potential $(n=4)$ (Fig. $1 D)$.

Using $\mathrm{KCl}$-based intracellular solution to increase the chloride driving force at resting membrane potential, since $\mathrm{E}_{\mathrm{Cl}}$ is 2 $\mathrm{mV}, 100 \mu \mathrm{M}$ bicuculline caused a negative shift of membrane potential $(2.4 \pm 0.4 \mathrm{mV}, p<0.001, n=11)$. This response was also maintained in the presence of $1 \mu \mathrm{M}$ external TTX (Fig. 2A). To test whether increased ambient GABA would augment tonic

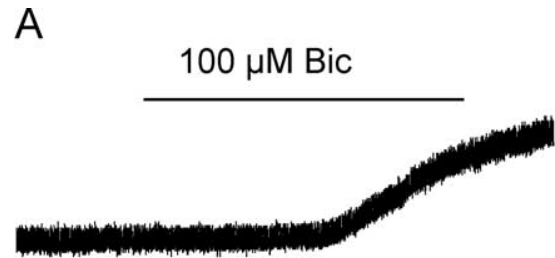

in $1 \mu \mathrm{M}$ TTX

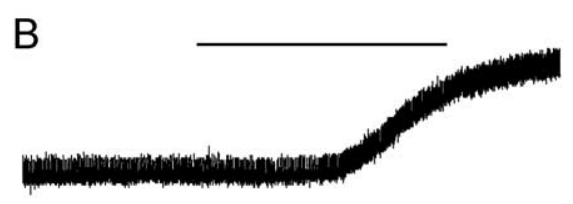

in $20 \mu \mathrm{M} \mathrm{CdCl}_{2}$

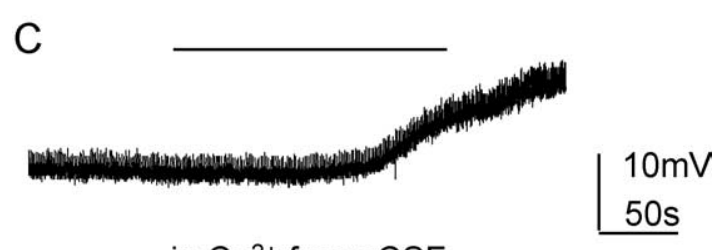

in $\mathrm{Ca}^{2+}$ free aCSF

Figure 3. Tonic inhibition recorded in $\mathrm{Cs}_{2} \mathrm{SO}_{4}$-based intracellular solution is unaffected by TTX or $\mathrm{Ca}^{2+}$-free solutions. $A$, When holding at $0 \mathrm{mV}$ in the presence of applied TTX $(1 \mu \mathrm{M})$, this SPN was depolarized by $100 \mu \mathrm{m}$ bicuculline. $\boldsymbol{B}$, Trace from the same neuron showing that the bicuculline response was maintained after addition of $\mathrm{Cd}^{2+}$ or $(\boldsymbol{C})$ in $\mathrm{Ca}^{2+}$-free extracellular solution.

GABAergic inhibition in SPNs, $2.5 \mu \mathrm{M}$ GABA was added to extracellular solution before application of bicuculline. The tonic inhibition revealed by $100 \mu \mathrm{m}$ bicuculline in GABA was significantly enhanced from $2.2 \pm 0.1 \mathrm{mV}$ to $3.4 \pm 0.7 \mathrm{mV}$ for all 5 cells tested (Fig. $2 B)(p<0.05)$.

Bicuculline salts also block Ca-dependent $\mathrm{K}$ channels which contribute to neuronal action potential afterhyperpolarizations and indirectly manipulates membrane potential (Khawaled et al., 1999). To block these channels and eliminate this influence, a Csbased TEA-containing pipette solution was used. Bicucullineinduced depolarizations were still observed $(10.1 \pm 1.6 \mathrm{mV}, n=$ $6, p<0.001)$ and also in the presence of $1 \mu \mathrm{M}$ external TTX $(n=$ 2) (Fig. 3A). Furthermore, this response was also preserved in 20 $\mu \mathrm{M} \mathrm{CdCl}{ }_{2}$ containing aCSF (Fig. $\left.3 B\right)(n=2)$ or $\mathrm{Ca}^{2+}$-free aCSF (Fig. 3C) $(n=2)$. This suggests that the bicuculline response was due to antagonizing $\mathrm{GABA}_{\mathrm{A}}$ receptor chloride channels and that GABAergic tonic inhibition in SPNs is $\mathrm{Ca}^{2+}$ independent.

\section{Tonic GABAergic inhibition in SPNs is insensitive to the} $\mathrm{GABA}_{\mathrm{A}}$ receptor antagonist gabazine

A variety of concentrations of gabazine were used to study its effectiveness on tonic GABAergic inhibition in SPNs, using K-gluconate-based intracellular solution. Gabazine at a concentration of $25 \mathrm{~nm}$ [which has shown previously to be effective at tonic receptors (Cope et al., 2005)] did not change membrane potential shift $(0 \pm 0.04 \mathrm{mV}$ to $0.2 \pm 0.1 \mathrm{mV})$ or input resistance $(692.9 \pm 53.0 \mathrm{M} \Omega$ to $694.8 \pm 51.2 \mathrm{M} \Omega, n=6, p>0.05)$ (Fig. $4 A 1)$ when SPNs were held at resting membrane potential. The addition of exogenous GABA $(1 \mu \mathrm{M})$ also failed to augment tonic GABAergic inhibition $(n=4)$ (Fig. 4A2). When the holding 

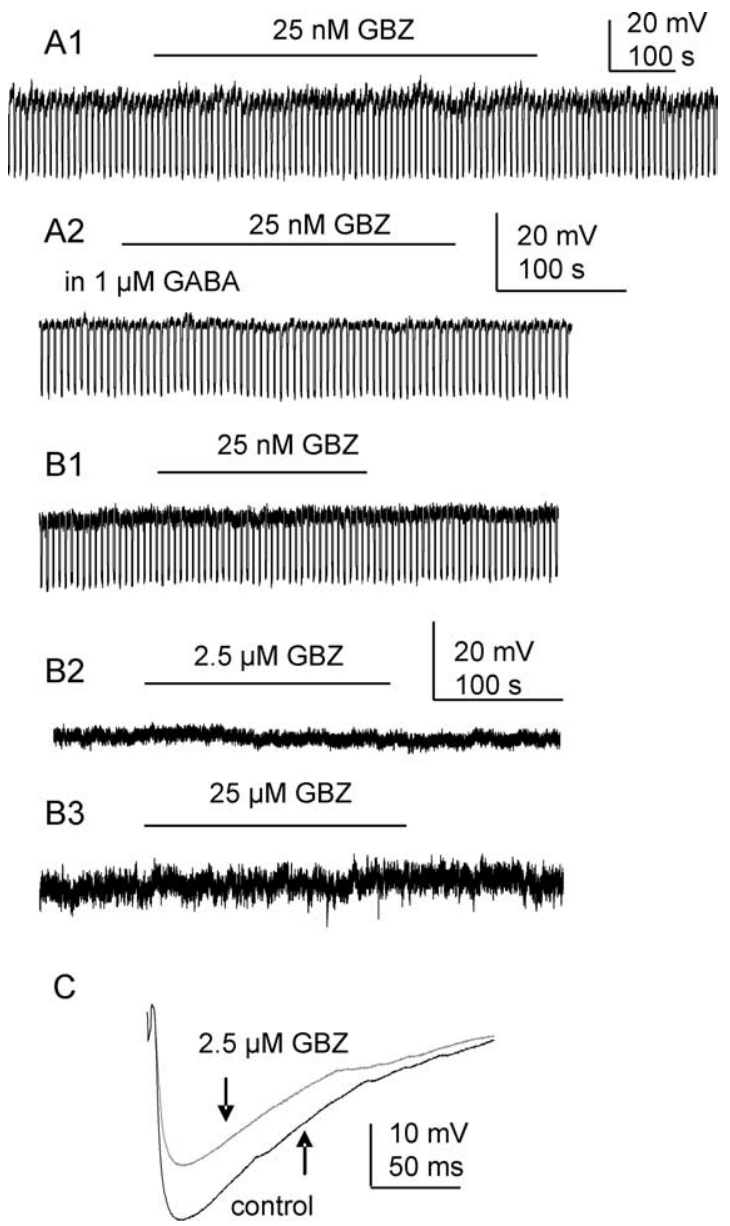

Figure 4. Tonic inhibition in SPNs is gabazine insensitive. A1, Recording from an SPN holding at resting membrane potential where gabazine (GBZ, $25 \mathrm{~nm}$ ) did not change membrane potential or cell input resistance. $\boldsymbol{A 2}$, In the presence of exogenous $G A B A$, gabazine still failed to alter cell holding potential. $\boldsymbol{B} \mathbf{1 - 3}$, At the holding potential of $0 \mathrm{mV}$, no tonic inhibition was detected when different concentrations of gabazine were applied. $C$, The amplitude of Lf-IPSPS was significantly reduced by $2.5 \mu \mathrm{m}$ gabazine $(p<0.05)$.

potential was changed to $0 \mathrm{mV}$, neither this concentration of gabazine $(n=4, p>0.05)$ (Fig. $4 B 1)$ nor higher concentrations [2.5 $\mu \mathrm{M}$ and up to $25 \mu \mathrm{M}$, a concentration that has previously been effective at abolishing pure GABAergic IPSCs but has no effect on tonic currents (Bieda and Maciver, 2004)] revealed a tonic current $(n=4, p>0.05)$ (Fig. 4 B2). In contrast, the amplitude of evoked IPSPs elicited by stimulating Lf was significantly reduced from $8.4 \pm 2.1$ to $4.5 \pm 1.0 \mathrm{mV}$ by $2.5 \mu \mathrm{M}$ gabazine $(n=7, p<0.05)$ (Fig. 4C).

\section{Tonic GABAergic inhibition in SPNs is mediated by $\alpha 5$ subunit-containing receptors}

To dissect out the possible composition of receptors mediating tonic GABAergic inhibition in SPNs, different subunit sensitive modulators were used. The classical benzodiazepine, diazepam, activates $\gamma 2$ subunit-containing receptors that also contain either $\alpha 1, \alpha 2, \alpha 3$ or $\alpha 5$ subunits (Pritchett et al., 1989; Pritchett and Seeburg, 1990). When using K-gluconate-based intracellular solution, after the bath application of $1 \mu \mathrm{M}$ diazepam, the membrane potential shift induced by bicuculline was significantly increased compared with the effect of bicuculline alone (from $2.8 \pm$ $0.8 \mathrm{mV}$ to $6.2 \pm 1.5 \mathrm{mV}$ ) while diazepam alone caused an average hyperpolarization of $2.4 \pm 0.5 \mathrm{mV}(n=4)$ (Fig. 5A3). Similar changes were observed in KCl-based intracellular solution recording with an increase in mean amplitude of depolarization from $2.2 \pm 0.7 \mathrm{mV}$ to $5.7 \pm 0.8 \mathrm{mV}(n=4, p<0.05)$. However, a more selective benzodiazepine site modulator, $2 \mu \mathrm{M}$ zolpidem, which acts at $\alpha 1, \alpha 2$ and $\alpha 3$ subunit-containing receptors, failed to induce the same response $(0.6 \pm 0.2 \mathrm{mV}$ to $0.7 \pm 0.2 \mathrm{mV}, p>$ $0.1)$ (Fig. 5A2) $(n=4$, in K-gluconate intracellular and $n=2$ in $\mathrm{KCl}$ intracellular). This strongly suggests that tonic GABAergic inhibition in SPNs is mediated by $\alpha 5 \gamma 2$ subunit-containing receptors.

The existence of $\delta$ subunit-containing receptor subtypes was also examined based on its unique pharmacological properties, i.e., sensitivity to neurosteroids and THIP. Bath application of THIP $(1 \mu \mathrm{M})$ alone did not induce apparent membrane potential changes $(p>0.05, n=4)$ (Fig. 5B3). There was also no significant enhancement of the bicuculline induced voltage changes either. Similar results were observed in THDOC $(100 \mathrm{nM})(n=4)$ (Fig. 5B2).

$\alpha 5$ but not $\delta$ subunits are expressed in the IML of spinal cord To further verify the presence in the IML of the different subunits that may contribute to this tonic inhibition, PCR was performed on punches of IML from spinal cord tissue of the same age, and prepared in the same way, as that used in the electrophysiological experiments.

PCR analysis was performed on CDNA samples taken from the spinal cord and IML. Expression of $\alpha 5$ was observed in all of the spinal cord and IML samples $(n=4)$ (Fig. $5 D)$, denoted by the presence of a single band corresponding to the predicted size (300 bp). Amplicons representing the $\delta$ isoform were not detected in either the spinal cord or IML samples despite multiple attempts (Fig. 5D). This isoform was present in the positive control tissue taken from the hypothalamus, confirming the negative results observed were not due to the primers or amplification conditions.

\section{Modulation of tonic inhibition influences SPN \\ firing properties}

Since tonic GABAergic inhibition plays an important role in regulating cell excitability in SPNs, the direct influence on membrane properties could affect sympathetic outflow. To test the membrane response to the antagonist bicuculline and modulator diazepam, whole-cell input resistance and action potential frequency were measured upon injecting currents.

Under control conditions, SPNs respond to depolarizing currents by firing of action potentials after reaching threshold. As the depolarizing current steps are increased, SPNs fire at higher frequency (Fig. 6A1). Application of $100 \mu \mathrm{M}$ bicuculline that would block the tonic GABAergic inhibition resulted in an increased firing rate in all 4 cells recorded (Fig. $6 A 2,3$ ). Consistently, when tonic GABAergic inhibition was enhanced by bath application of diazepam, the associated response to negative current pulses was a reduced whole-cell input resistance and a lowered firing rate in response to positive currents (Fig. $6 B)(n=4)$.

\section{Interneurons do not display tonic GABAergic inhibition}

The lateral horn of the thoracic spinal cord also contains interneurons that directly project to SPNs (Deuchars, 2007). These neurons can be instantly differentiated from principal neurons during whole-cell patch-clamp recording by their electrophysiological properties (Deuchars et al., 2001). In all 5 interneurons recorded, holding at $0 \mathrm{mV}, 100 \mu \mathrm{M}$ bicuculline failed to uncover a tonic inhibition since membrane potentials were not signifi- 
A1
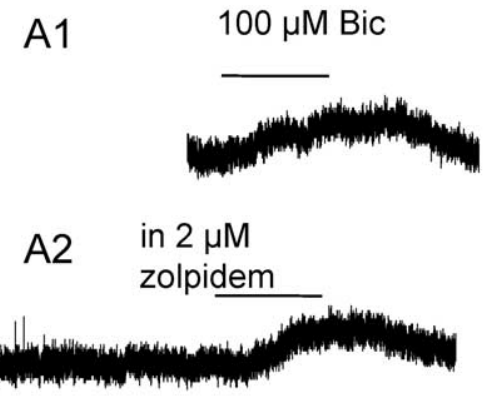

A3

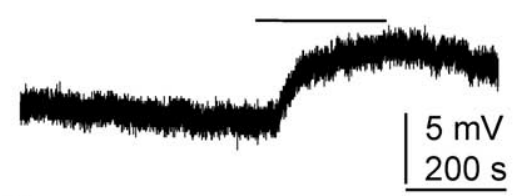

C

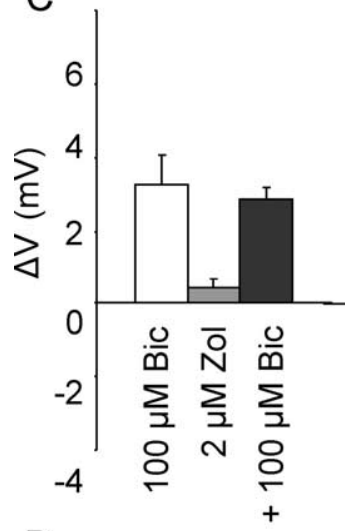

D $\alpha 5$
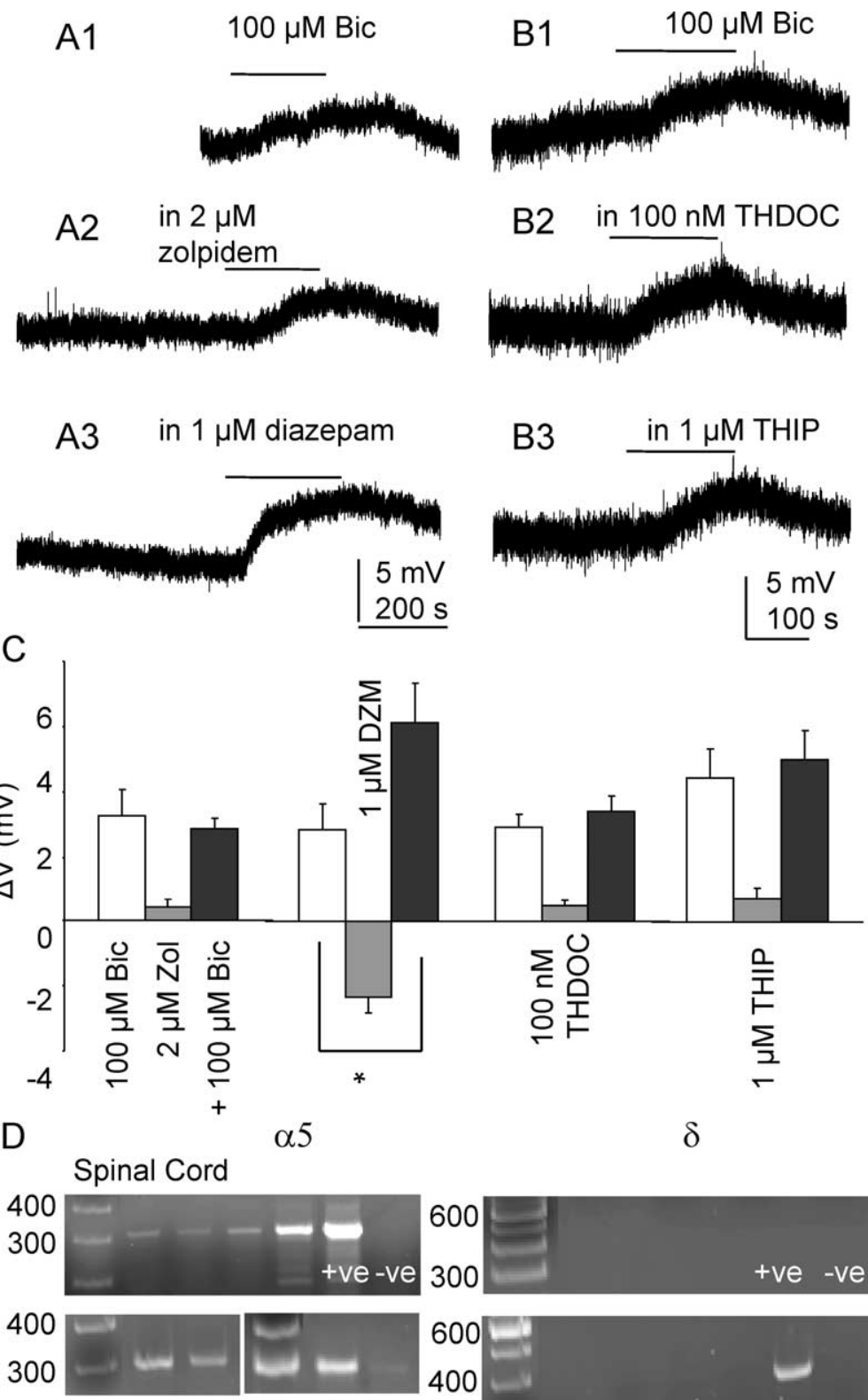

IML

Figure 5. Tonic inhibition is mediated by $\alpha 5$ subunit-containing $G_{A B A_{A}}$ receptors. Recordings made in $\mathrm{K}$-gluconate-based intracellular solution. Lines indicate application of $100 \mu \mathrm{m}$ bicuculline. A1-3, Reponses to $100 \mu \mathrm{m}$ bicuculline in the same neuron in control conditions, in $2 \mu \mathrm{m}$ zolpidem and $1 \mu \mathrm{m}$ diazepam (DZM). B1-3, Responses to $100 \mu \mathrm{m}$ bicuculline in the same neuron in control conditions, in $100 \mathrm{~nm}$ THDOC and $1 \mu \mathrm{M}$ THIP. C, Graph showing membrane potential changes to bath application of 100 $\mu \mathrm{m}$ bicuculline alone (white bars), modulators alone (gray bars), and bicuculline in the presence of a modulator (black bars). ${ }^{*} p<$ 0.001 , Student paired $t$ test. Error bars represent SEM. D, Expression of $\alpha 5$ in the spinal cord and IML sample, denoted by the presence of a single band corresponding to the predicted size $(300 \mathrm{bp})$. Amplicons representing the $\delta$ isoform are not detected in either the spinal cord or IML samples. This isoform is however present in the positive control tissue (+ve) taken from the hypothalamus, confirming the negative results observed are not due to the primers or amplification conditions.

to activation of specific extrasynaptic rather than synaptic receptors.

\section{Discussion}

Our data show a novel and widespread effect of tonically active GABA receptors on SPNs, but not interneurons, in the IML of rat spinal cord. Blockade of these receptors increased the firing rate of SPNs in response to a depolarizing current pulse while enhancement of the inhibition reduced the numbers of action potentials. This finding suggests that these tonically active GABA receptors may contribute to setting the level of excitability in SPNs, thus having a potentially extensive effect on sympathetic outflow. The pharmacological profile of this inhibition combined with PCR data suggests that this tonic inhibition is mediated by activation of $\alpha 5$ subunit-containing receptors.

\section{GABA receptor composition}

Tonic inhibition in SPNs was enhanced by diazepam indicating that the receptor involved is likely to contain $\alpha$ and $\gamma 2$ subunits. Resistance to high concentrations of zolpidem rules out the involvement of $\alpha 1$, 2 or 3 subunits (Pritchett et al., 1989; Pritchett and Seeburg, 1990), which leaves a most likely receptor combination of $\alpha 5 \gamma 2$ subunits. Another group of extrasynaptic receptors mediating tonic current contains the $\delta$ subunit. Sensitivity to benzodiazepine does not necessarily exclude the possibility of coexistence of $\delta$ and $\alpha 5$ subunit-containing receptors; however, insensitivity to the agonist THIP and neurosteroid THDOC contradicts a contribution from this subunit. Moreover, our RTPCR data indicate robust expression of $\alpha 5$ but not $\delta$ subunits in the IML. The absence of an amplicon was determined not to be a "false-negative" result. All the reactions were run concurrently and positive expression was seen for $\alpha 5$ in the same cDNA samples and for $\delta$ in cDNA samples from the hypothalamus. Therefore we are confident that the cDNA concentration and primers were optimal for these reactions. In addition, increasing the amount of starting template failed to produce a positive signal. This finding is substantiated by immunohistochemical and in situ hybrid-

cantly altered (from $0.24 \pm 0.2$ to $0.38 \pm 0.6 \mathrm{mV}$ ) (Fig. $7 A)(p>$ $0.05)$. When exogenous GABA $(1 \mu \mathrm{M})$ was added, it alone did not have any effect on holding potential nor did it induce any bicuculline response $(0.87 \pm 0.7 \mathrm{mV}, n=3)$ (Fig. $7 B)$. Compared with the tonic GABAergic inhibition revealed in SPNs, this result indicates that interneurons in the lateral horn are not tonically inhibited by $\mathrm{GABA}_{\mathrm{A}}$ receptors. Furthermore, the fact that spontaneous IPSPs were completely abolished by bicuculline (Fig. $7 C$ ), without effect on the membrane potential lends further support to the idea that the inhibition observed in SPNs is indeed due ization studies from the spinal cord which show a similar lack of $\delta$ subunits (Wisden et al., 1991; Persohn et al., 1992; Bohlhalter et al., 1996).

This $\alpha 5 \gamma 2$ subunit combination is also the predominant receptor underlying tonic inhibition in other regions of the CNS where $\gamma 2$ subunits predominate and the $\delta$ subunit is decreased (Pirker et al., 2000), e.g., hippocampal CA1 neurons (Bai et al., 2001; Stell and Mody, 2002; Caraiscos et al., 2004), cortical layer $\mathrm{V}$ (Yamada et al., 2007). In cultured cells and recombinant ion 
channels, $\alpha \beta$ receptors can also mediate tonic current (Mortensen and Smart, 2006), but insensitivity to THIP rules out their contribution in this study.

\section{Effects of different GABA antagonists}

Our data show a sensitivity of the GABAergic tonic inhibition in SPNs to bicuculline and picrotoxin but not gabazine. Similarly, in hippocampal pyramidal neurons (Bai et al., 2001; Bieda and MacIver, 2004; McCartney et al., 2007), parasympathetic cardiac neurons of the nucleus ambiguus (Bouairi et al., 2006) and second order neurons of the nucleus of the solitary tract (McDougall et al., 2008), tonic currents are gabazine insensitive. In dentate gyrus granule cells (Stell and Mody, 2002), the effect of gabazine on tonic current is more complex with insensitivity of the tonic current to low concentrations of gabazine (200 nM) but blockade at higher concentrations $(10 \mu \mathrm{M})$. This differential sensitivity may reflect differences in the mechanisms underlying activation of the receptors responsible for tonic inhibition (see below).

\section{Possible mechanisms underlying tonic inhibition}

Tonic current is cell-type dependent and can be affected by multiple factors. There are two possible mechanisms underlying maintenance of a tonic current. First, receptors are activated by low concentrations of background GABA. Ambient GABA could be from several different sources, e.g., spillover from synaptic site during vesicle release (Kaneda et al., 1995; Brickley et al., 1996), nonvesicular action potential-independent transmitter release (Attwell et al., 1993; Wall and Usowicz, 1997; Richerson and Wu, 2003; Rossi et al., 2003) or glial release (Liu et al., 2000; Kozlov et al., 2006). In contrast to a synaptic event where GABA could be raised to millimolar level, a nanomolar concentration is sufficient for tonic inhibition (Santhakumar et al., 2006). Consequently, receptors which mediate tonic current have higher affinities and lower desensitization rates. We show that tonic inhibition is insensitive to TTX suggesting that there is sufficient ambient GABA from sources other than action potential dependent synaptic release. Second, some receptors can be spontaneously activated without ligand triggering (Birnir et al., 2000; McCartney et al., 2007), indeed the lack of sensitivity of tonic currents to gabazine may be an indication that in these cases the effects are due to spontaneous GABA receptor gating in the absence of GABA (McCartney et al., 2007).

Tonic GABAergic inhibition in SPNs is unlikely to be an artifact of development, state of slices or lowered temperature We have demonstrated that tonic GABAergic inhibition is present in all SPNS tested in thoracic IML; however, these experiments are performed on tissue from rats aged $10-15 \mathrm{~d}$ which are considered immature. It is likely though that such tonic inhibition persists in adult and may even increase in relative contribution of overall GABAergic inhibition. Tonic GABAergic inhibi- tion is reported in adult rat hippocampal, cortical and cerebellar slices (Brickley et al., 1996; Wall and Usowicz, 1997). Indeed in cerebellar granule cells, the amplitude of the tonic current increased and in mature rats was TTX insensitive (similar to our results) suggesting that the source of GABA in adult rats is unlikely to be due to action potential dependant spillover of GABA from synaptic terminals. These changes in amplitudes of tonic GABA currents with age may be due to developmental changes in local morphology, for example, the size of the synaptic cleft, density of the local surrounding cells, or status of axonal myelination (Semyanov et al., 2004). The more complex the local environment, the more transmitter molecules might be trapped after any source of release therefore increasing their chances of activating the extrasynaptic site. Wall and Usowicz (1997) also reported that the tonic current persisted at near physiological temperatures, ruling out the possibility that the tonic inhibition was due to less efficient clearance of GABA from the extracellular space. Transmitter leaking from unhealthy or dead cells (Rossi et al., 2003) might cause a common bias in slice recordings, especially in the very demanding spinal cord preparation. However, this is likely to be limited by the care applied in practice, such as resting slices before experiments, maintaining high perfusion rates and commencing recording once slices are stable.

\section{Functional significance of tonic GABAergic inhibition}

The level of sympathetic outflow is a direct outcome of the excitability of the SPNs. Tonic inhibition in general increases the entire conductance of cells as a population (Mody and Pearce, 
A

\section{$100 \mu \mathrm{M}$ Bic}

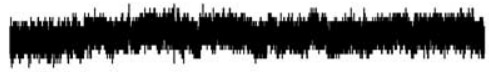

B

$100 \mu \mathrm{M}$ Bic

\section{$10 \mathrm{mV}$ $100 \mathrm{~s}$}

in $1 \mu \mathrm{M}$ GABA

C
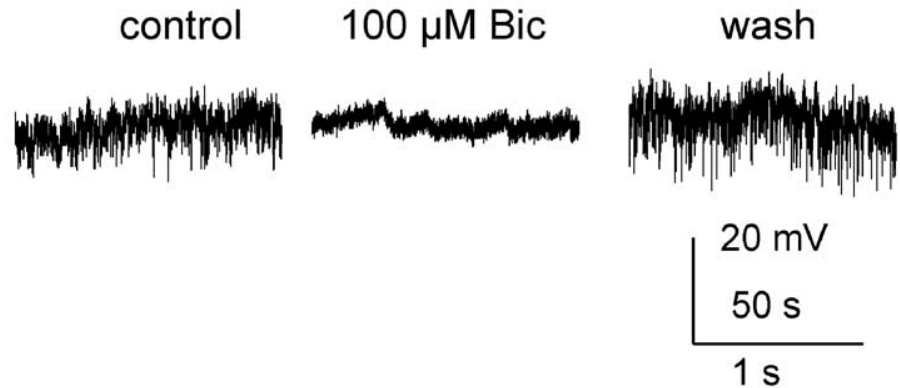

control

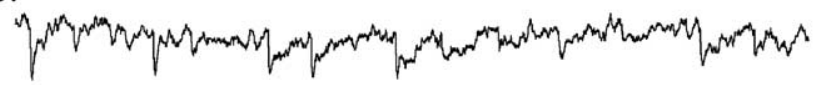

\section{$100 \mu \mathrm{M}$ Bic}

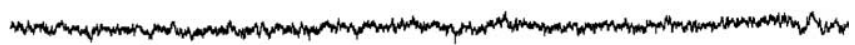

wash

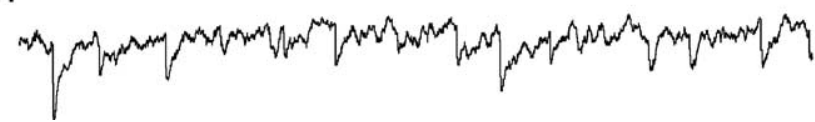

Figure 7. No tonic inhibition was detected in interneurons in the IML. $\boldsymbol{A}$, Recording from an interneuron using K-gluconatebased intracellular solution at a holding potential of $0 \mathrm{mV}$. No membrane potential change was detected during bath application of $100 \mu \mathrm{m}$ bicuculline. $\boldsymbol{B}$, Trace from the same cell after addition of extracellular GABA. C, Trace from a different interneuron using K-gluconate-based intracellular solution at $0 \mathrm{mV}$ holding potential. Spontaneous IPSPs were seen under control conditions (shown in expanded traces at the bottom) and were blocked by $100 \mu \mathrm{m}$ bicuculline without changing cell membrane potential.

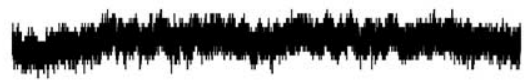

to modulation of central pathways and may be due in part to contribution of these tonic receptors. Zolpidem in contrast had no significant effect on blood pressure in humans (Cashman et al., 1987) or in rats (Mailliet et al., 2001). Others report conflicting changes in RR intervals, depending on the dose of zolpidem administered but mainly due to a change in cardiac vagal tone, rather than on sympathetic outflow (Chen et al., 2005). These data fit well with our report of the effects of different modulators on tonic GABA inhibition.

A steady sympathetic tone is critical under physiological circumstances, for example, chronic hypertension causes irreversible pathological changes in the arterial system while a sharp increase in blood pressure may induce an acute arterial rupture. To this extent, the existence of tonic inhibition in SPNs could both slow down the development of high blood pressure and attenuate the level of sudden changes in arterial pressure. Therefore, our report of tonic inhibition in SPNs might lead research in blood pressure regulation to a new direction.

In conclusion, our results show effects on all SPNs at the upper thoracic levels, indicative of a profound effect of tonic GABA inhibition on the level of excitability in sympathetic outflow from the spinal cord. These data propose a novel mechanism by which sympathetic tone is set by SPNs sensing the levels of ambient GABA. Such a mechanism could prove to be an important target for therapies where reduced sympathetic tone is required, such as obesity induced hypertension.

\section{References}

Attwell D, Barbour B, Szatkowski M (1993)

Nonvesicular release of neurotransmitter. Neuron 11:401-407.

Bai D, Zhu G, Pennefather P, Jackson MF, MacDonald JF, Orser BA (2001) Distinct functional and pharmacological properties of tonic and quantal inhibitory postsynaptic currents mediated by gamma-aminobutyric acid(A) receptors in hippocampal neurons. Mol Pharmacol 59:814-824.

2004). Therefore, the level of response to an external stimulus at a cellular level can be reduced compared with cells with no tonic "buffering" system. Such a global tonic inhibitory influence on the level of activity in SPNs would have extensive effects on many end organs, including the heart and blood vessels. Interestingly, the hemodynamic effects of the two GABA modulators used in this study, diazepam (which enhanced tonic inhibition due to nonselective effects on all $\alpha$ subunits) and zolpidem (which had no effect since it has little influence on $\alpha 5$ subunits) fit with the idea that this tonic inhibition may contribute to overall blood pressure changes. Diazepam causes hypotension and overall decreases in muscle sympathetic activity in humans (Kitajima et al., 2004), that is partly attributed to decreases in levels of circulating epinephrine (Marty et al., 1986). In dogs, the baroreceptor reflex sensitivity is also attenuated (Taneyama et al., 1993). A high proportion of the hemodynamic effects of diazepam were attributed ieda MC, MacIver MB (2004) Major role for tonic GABAA conductances in anesthetic suppression of intrinsic neuronal excitability. J Neurophysiol 92:1658-1667.

Birnir B, Everitt AB, Lim MS, Gage PW (2000) Spontaneously opening $\mathrm{GABA}(\mathrm{A})$ channels in CA1 pyramidal neurones of rat hippocampus. Membr Biol 174:21-29.

Bohlhalter S, Weinmann O, Mohler H, Fritschy JM (1996) Laminar compartmentalization of $\mathrm{GABA}_{\mathrm{A}}$-receptor subtypes in the spinal cord: an immunohistochemical study. J Neurosci 16:283-297.

Bouairi E, Kamendi H, Wang X, Gorini C, Mendelowitz D (2006) Multiple types of $\mathrm{GABA}_{\mathrm{A}}$ receptors mediate inhibition in brain stem parasympathetic cardiac neurons in the nucleus ambiguus. J Neurophysiol 96:3266-3272.

Brickley SG, Cull-Candy SG, Farrant M (1996) Development of a tonic form of synaptic inhibition in rat cerebellar granule cells resulting from

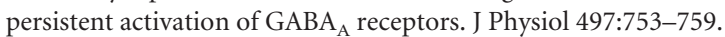


Caraiscos VB, Elliott EM, You-Ten KE, Cheng VY, Belelli D, Newell JG, Jackson MF, Lambert JJ, Rosahl TW, Wafford KA, MacDonald JF, Orser BA (2004) Tonic inhibition in mouse hippocampal CA1 pyramidal neurons is mediated by alpha5 subunit-containing gamma-aminobutyric acid type A receptors. Proc Natl Acad Sci U S A 101:3662-3667.

Cashman JN, Power SJ, Jones RM (1987) Assessment of a new hypnotic imidazo-pyridine (zolpidem) as oral premedication. Br J Clin Pharmacol 24:85-92.

Chen HY, Kuo TB, Shaw FZ, Lai CJ, Yang CC (2005) Sleep-related vagotonic effect of zolpidem in rats. Psychopharmacology (Berl) 181:270-279.

Cope DW, Hughes SW, Crunelli V (2005) GABA $_{\mathrm{A}}$ receptor-mediated tonic inhibition in thalamic neurons. J Neurosci 25:11553-11563.

Dembowsky K, Czachurski J, Seller H (1985) An intracellular study of the synaptic input to sympathetic preganglionic neurones of the third thoracic segment of the cat. J Auton Nerv Syst 13:201-244.

Deuchars SA (2007) Multi-tasking in the spinal cord-do 'sympathetic' interneurones work harder than we give them credit for? J Physiol 580:723-729.

Deuchars SA, Spyer KM, Gilbey MP (1997) Stimulation within the rostral ventrolateral medulla can evoke monosynaptic GABAergic IPSPs in sympathetic preganglionic neurons in vitro. J Neurophysiol 77:229-235.

Deuchars SA, Brooke RE, Frater B, Deuchars J (2001) Properties of interneurones in the intermediolateral cell column of the rat spinal cord: role of the potassium channel subunit Kv3.1. Neuroscience 106:433-446.

Eugène E, Depienne C, Baulac S, Baulac M, Fritschy JM, Le Guern E, Miles R, Poncer JC (2007) $\mathrm{GABA}_{\mathrm{A}}$ receptor $\gamma-2$ subunit mutations linked to human epileptic syndromes differentially affect phasic and tonic inhibition. J Neurosci 27:14108-14116.

Francischetti EA, Genelhu VA (2007) Obesity-hypertension: an ongoing pandemic. Int J Clin Pract 61:269-280.

Ghavanini AA, Mathers DA, Puil E (2005) Glycinergic inhibition in thalamus revealed by synaptic receptor blockade. Neuropharmacology 49:338-349.

Glykys J, Mody I (2007) Activation of GABAA receptors: views from outside the synaptic cleft. Neuron 56:763-770.

Hussy N, Deleuze C, Pantaloni A, Desarménien MG, Moos F (1997) Agonist action of taurine on glycine receptors in rat supraoptic magnocellular neurones: possible role in osmoregulation. J Physiol 502:609-621.

Kaneda M, Farrant M, Cull-Candy SG (1995) Whole-cell and singlechannel currents activated by GABA and glycine in granule cells of the rat cerebellum. J Physiol 485:419-435.

Khawaled R, Bruening-Wright A, Adelman JP, Maylie J (1999) Bicuculline block of small-conductance calcium-activated potassium channels. Pflugers Arch 438:314-321.

Kitajima T, Kanbayashi T, Saito Y, Takahashi Y, Ogawa Y, Sugiyama T, Kaneko Y, Aizawa R, Shimizu T (2004) Diazepam reduces both arterial blood pressure and muscle sympathetic nerve activity in human. Neurosci Lett 355:77-80.

Kozlov AS, Angulo MC, Audinat E, Charpak S (2006) Target cell-specific modulation of neuronal activity by astrocytes. Proc Natl Acad Sci U S A 103:10058-10063.

Li Y, Wu LJ, Legendre P, Xu TL (2003) Asymmetric cross-inhibition between GABAA and glycine receptors in rat spinal dorsal horn neurons. J Biol Chem 278:38637-38645.

Liu QY, Schaffner AE, Chang YH, Maric D, Barker JL (2000) Persistent activation of $\mathrm{GABA}(\mathrm{A})$ receptor/Cl(-) channels by astrocyte-derived GABA in cultured embryonic rat hippocampal neurons. J Neurophysiol 84:1392-1403.

Mailliet F, Galloux P, Poisson D (2001) Comparative effects of melatonin, zolpidem and diazepam on sleep, body temperature, blood pressure and heart rate measured by radiotelemetry in Wistar rats. Psychopharmacology (Berl) 156:417-426.

Marty J, Gauzit R, Lefevre P, Couderc E, Farinotti R, Henzel C, Desmonts JM (1986) Effects of diazepam and midazolam on baroreflex control of heart rate and on sympathetic activity in humans. Anesth Analg 65:113-119.

McCartney MR, Deeb TZ, Henderson TN, Hales TG (2007) Tonically active
GABAA receptors in hippocampal pyramidal neurons exhibit constitutive GABA-independent gating. Mol Pharmacol 71:539-548.

McDougall SJ, Bailey TW, Mendelowitz D, Andresen MC (2008) Propofol enhances both tonic and phasic inhibitory currents in second-order neurons of the solitary tract nucleus (NTS). Neuropharmacology 54:552-563.

Meldrum BS, Rogawski MA (2007) Molecular targets for antiepileptic drug development. Neurotherapeutics 4:18-61.

Mody I, Pearce RA (2004) Diversity of inhibitory neurotransmission through GABA(A) receptors. Trends Neurosci 27:569-575.

Mortensen M, Smart TG (2006) Extrasynaptic alphabeta subunit GABAA receptors on rat hippocampal pyramidal neurons. J Physiol 577:841-856.

Otis TS, Staley KJ, Mody I (1991) Perpetual inhibitory activity in mammalian brain slices generated by spontaneous GABA release. Brain Res 545:142-150.

Peng Z, Huang CS, Stell BM, Mody I, Houser CR (2004) Altered expression of the $\delta$ subunit of the $\mathrm{GABA}_{\mathrm{A}}$ receptor in a mouse model of temporal lobe epilepsy. J Neurosci 24:8629-8639.

Persohn E, Malherbe P, Richards JG (1992) Comparative molecular neuroanatomy of cloned GABAA receptor subunits in the rat CNS. J Comp Neurol 326:193-216.

Pirker S, Schwarzer C, Wieselthaler A, Sieghart W, Sperk G (2000) GABA(A) receptors: immunocytochemical distribution of 13 subunits in the adult rat brain. Neuroscience 101:815-850.

Pritchett DB, Seeburg PH (1990) Gamma-aminobutyric acidA receptor alpha 5-subunit creates novel type II benzodiazepine receptor pharmacology. J Neurochem 54:1802-1804.

Pritchett DB, Lüddens H, Seeburg PH (1989) Type I and type II GABAAbenzodiazepine receptors produced in transfected cells. Science 245:1389-1392.

Richerson GB, Wu Y (2003) Dynamic equilibrium of neurotransmitter transporters: not just for reuptake anymore. J Neurophysiol 90:1363-1374.

Rossi DJ, Hamann M, Attwell D (2003) Multiple modes of GABAergic inhibition of rat cerebellar granule cells. J Physiol 548:97-110.

Santhakumar V, Hanchar HJ, Wallner M, Olsen RW, Otis TS (2006) Contributions of the $\mathrm{GABA}_{\mathrm{A}}$ receptor $\alpha 6$ subunit to phasic and tonic inhibition revealed by a naturally occurring polymorphism in the $\alpha 6$ gene. J Neurosci 26:3357-3364.

Semyanov A, Walker MC, Kullmann DM, Silver RA (2004) Tonically active GABA A receptors: modulating gain and maintaining the tone. Trends Neurosci 27:262-269.

Spary EJ, Maqbool A, Saha S, Batten TF (2008) Increased GABA(B) receptor subtype expression in the nucleus of the solitary tract of the spontaneously hypertensive rat. J Mol Neurosci 35:211-224.

Stell BM, Mody I (2002) Receptors with different affinities mediate phasic and tonic $\mathrm{GABA}_{\mathrm{A}}$ conductances in hippocampal neurons. J Neurosci 22:RC223.

Taneyama C, Goto H, Kohno N, Benson KT, Sasao J, Arakawa K (1993) Effects of fentanyl, diazepam, and the combination of both on arterial baroreflex and sympathetic nerve activity in intact and baro-denervated dogs. Anesth Analg 77:44-48.

Tentolouris N, Liatis S, Katsilambros N (2006) Sympathetic system activity in obesity and metabolic syndrome. Ann N Y Acad Sci 1083:129-152.

Wall MJ, Usowicz MM (1997) Development of action potential-dependent and independent spontaneous GABAA receptor-mediated currents in granule cells of postnatal rat cerebellum. Eur J Neurosci 9:533-548.

Whyment AD, Wilson JM, Renaud LP, Spanswick D (2004) Activation and integration of bilateral GABA-mediated synaptic inputs in neonatal rat sympathetic preganglionic neurones in vitro. J Physiol 555:189-203.

Wisden W, Gundlach AL, Barnard EA, Seeburg PH, Hunt SP (1991) Distribution of GABAA receptor subunit mRNAs in rat lumbar spinal cord. Brain Res Mol Brain Res 10:179-183.

Yamada J, Furukawa T, Ueno S, Yamamoto S, Fukuda A (2007) Molecular basis for the GABAA receptor-mediated tonic inhibition in rat somatosensory cortex. Cereb Cortex 17:1782-1787.

Zhang N, Wei W, Mody I, Houser CR (2007) Altered localization of GABA receptor subunits on dentate granule cell dendrites influences tonic and phasic inhibition in a mouse model of epilepsy. J Neurosci 27:7520-7531. 